\title{
Corporate Social Responsibility in Small and Medium Scale Enterprises in Nigeria: An Example from the Hotel Industry
}

\author{
Eme Joel Efiong ${ }^{1}$, Obal U. E. Usang ${ }^{2}$, Inyang O. Inyang ${ }^{2} \&$ Charles Effiong ${ }^{2}$ \\ ${ }^{1}$ Faculty of Business and Law, Leicester Business School, De Montfort University, Leicester, United Kingdom \\ 2 Department of Accounting, University of Calabar, Calabar Nigeria \\ Correspondence: Eme Joel Efiong, Faculty of Business and Law, Leicester Business School, De Montfort \\ University, Leicester, United Kingdom. Tel: 44-744-895-8198. E-mail: emetom@yahoo.com
}

Received: December 9, 2012 Accepted: May 21, 2013 Online Published: June 18, 2013

doi:10.5539/ijbm.v8n14p119 URL: http://dx.doi.org/10.5539/ijbm.v8n14p119

\begin{abstract}
Corporate social responsibility (CSR) is the promise by business organizations to behave in a way that is ethically acceptable and at the same time contributing to the economic development and improvement of the living conditions of the employees, the catchment community and the larger society. Small and medium scale enterprises (SMEs) can serve as the engine room for corporate social responsibility in developing countries, like Nigeria, since a high proportion of economic activity is generated through them. Hotel industry, belonging to this group has expanded rapidly since the return to democratic rule in 1999 primarily due to government's interest in tourism development. Such expansion of the hotel industry calls for an enquiry into how socially responsible its activities are. Hence, this study explored the corporate social responsibility of the hotel industry in Nigeria. Primarily, the study made use of quantitative data obtained though questionnaire administered on the management officers in these hotels. It was found out that corporate social responsibility practices are minimal and at an informal level. It is recommended that corporate social responsibility should be embraced by the small and medium scale enterprises in order to fast track the country's overall development.
\end{abstract}

Keywords: corporate social responsibility, small and medium scale enterprises, tourism, hotel industry, Nigeria

\section{Introduction}

Corporate social responsibility (CSR) is the promise by business organizations to behave in a way that is ethically acceptable and at the same time contributing to the economic development and improvement of the living conditions of the employees, the catchment community and the larger society (Azende, n.d). It is the set of conditions to which a company relates its impact on society with. The major advantages of corporate social responsibility are its potentials to bring about sustainable development and contribute to poverty reduction in any given society. Corporate social responsibility is the contributions of the organization to the development of the community in which such organizations is found in term of the social, economic, political, educational involvements. However, the company is not compelled to do by any law to do it (Adebayo, 1998).

Corporate social responsibility (CSR), relates to the role and obligations expected of business as a creation of modern society. Two opposing schools of thought emerged during the early birth of CSR. While one school argues that businesses should assume some responsibilities in the society beyond their primary economic role, the other stands against. In the later case, CSR is based on purely its economic role of profit. This is regarded as the "classical view", based on the neoclassical economic theory while the former which is the "stakeholder view", is based on stakeholder theory (Branco and Rodriques, 2007). However, businesses of different sizes and concerns are competing to be seen as socially responsible (Crowther, 2004). Social responsibility has now become the art of every business, whether small and medium enterprises or large corporations.

There is now an increased level of awareness of the important functions of small and medium scale enterprises in most developing countries, including Nigeria, particularly in the informal sector of the economy in terms of supply and creation of employment. In Africa, for instance, the informal sector is so large that it is more like a parallel economy. On the average the informal economy in Africa is estimated to have been 42 per cent in 1999/2000. At the country level, Nigeria's informal sector is at a high end with 59.4 per cent of GDP (http://rru.worldbank.org). It is generally believed that the small and medium scale enterprises (SMEs) can serve as the engine room for corporate social responsibility (CSR) in developing countries, because a high proportion of economic activity is 
generated by them.

Small and Medium-Scale Enterprises (SMEs) is one key area which can help in the development of the Nigerian economy. According to NCI (2003), a small-scale industry is an enterprise with total cost above N1.5m but less than N50m with a workforce of between 11 and 100 workers. Similarly, a medium-scale industry has a total cost of $50 \mathrm{~m}$ and above but less than 200 million, with a work force of between 101 and 300 workers.

However, according to Operational Guidelines of Small and Medium Enterprises Equity Investment scheme SMEEIS (2005) a small and medium enterprise has been defined as an enterprise with a maximum assets base $500 \mathrm{~m}$ and with no limits with regards to the size of the work force. Ariyo (2005) has noted the important roles played by SMEs in the growth and sustainable development of any economy as they serve as the strong support of any nation that has been industrialised. This is also the view of Kpelai (2009) as SMEs form the bulk of business enterprises in developed and developing economies like Nigeria.

Nigeria gained its independence from Britain in 1960 and became a republic in 1963. Nigeria presently consists of thirty-six (36) states and the Federal Capital Territory (FCT), Abuja. Cross River is one of the States of Nigeria. The country has more than 250 ethnic groups with varying languages and customs. There are over 500 languages spoken in Nigeria. According to the National Planning Commission (2004), over two-thirds of the Nigerian human population is poor. In 1980 an estimated 27 per cent of Nigerians lived in poverty, but by 1990, 70 per cent of the population lived with an income of less than one dollar a day. However, Nigeria has a strong potential for poverty-reduction currently. While progress has been made in this direction, much still remain to be done, particularly through the small and medium scale enterprises.

Hotel industry, belonging to this group (SMEs) has expanded rapidly since the return to democratic rule in 1999 primarily due to government's interest in tourism development. Such expansion of the hotel industry calls for an enquiry into how socially responsible its activities are. Hence, this study therefore explored the CSR of the hotel industry in Nigeria, and particularly in Cross River State.

\section{Conceptual Framework and Review of Literature}

\subsection{Conceptual Framework}

The concept of corporate social responsibility was originally coined in the 1930's, but its first appearance in academic work is found in Bowen (1953) in his book, 'Corporate Responsibility of the Businessman'. The concept of Corporate Social Responsibility One of the key indicators that determines the true worth and value of modern organizations is their ability to give back to the society part of their income through some mutually beneficial initiatives. These initiatives are encapsulated in the concept of CSR. The management literature is replete with various definitions of CSR, yet no single definition has been agreed upon as representing the concept (Obalola, 2010). Corroborating this view, Crowther and Jatana (2005) argued that, social responsibility is in vogue at the moment and means different things to different people. According to Adebayo (1998) CSR is what an organization does to contribute to the social, economic, political or educational development of the community where it is located, but which it is not compelled to do by any law. The first books on CSR were published in the 1930's (Windell, 2006). However, the real idea of corporate social responsibilty in the West has its beginning in 1948, after World War 2, when the United Nations created the Human Rights Declaration. This concept was followed by the ILO Declaration on Fundamental Principals and Rights at Work in 1972.

Davies (2003) as quoted by Helg (2007) describes how the concept of CSR emerged first in the 1960's among internationalizing companies from America and those involved in former colonial states in Africa and Asia. A number of authors in the final quarter of the last century observed that the activities of organisations have impacts on the external environment. The writers opined that companies should not only be accountable to their shareholders but also to other stakeholders. These concerns first appeared in the 1970s. For instance, "Ackerman in 1975 argued that companies were realizing the need to adapt to a new social climate of community responsibilities" (Helg, 2007). However, the right of all stakeholders is a relatively new phenomenon (Crowther \& Rayman-Bacchus, 2004). Nevertheless, there are also arguments against the concept of corporate social responsibility. Milton Friedman debated against corporate social responsibility in New York Times Magazine in 1970, where he was quoted: "there is only one and only one social responsibility of business - to use its resources and engage in activities designed to increase its profits so long as its stays within the rules of the game, which is to say, engages in open and free competition without deception or fraud" (Windell, 2006). In spite of that, corporate social responsibility is central to the corporate survival, there exists deepening controversy on how much resources a corporate organization should commit to social causes.

However, social responsibility marginally contributing to profits is more readily met than those not contributing to 
it in practice (Umoh, 1983). It therefore suggests that, social responsibility is a by-product of profitability. Researchers have shown that firms which anchor their performance on corporate social responsibility are the most profitable overtime (Harrison and Freeman, 1999; Barrett, 1998). Hence, corporate social responsibility is about the organization working towards profit maximization within the ambit of the laws and ethics, being socially responsible and responsive to the society. However, profitability is not the only benefit associated with corporate social responsibility. Hodgson (2005) has noted other critical benefits of concerted commitment to corporate social responsibility to include a strong reputation and improved corporation brand recognition; being exemplified as responsible by stakeholders; sustainable product brand loyalty; and improved government and community relations.

Corporate social responsibility therefore concerns all organizations. However, the rapid expansion in the hotel industry driven by tourism attracts our attention here with respect to what they are giving back to the society.

\subsection{Review of Literature}

The concept of corporate social responsibility may be thought to be relatively new, but one can trace its practices back in history. For example, the Holy Bible in Leviticus 19: 9-10, has this to say: When you reap the harvest of your land, you shall not wholly reap the corners of your field, nor shall you gather the gleanings of your harvest. And you shall not glean your vineyard, nor shall you gather every grape of your vineyard; you shall leave them for the poor and the stranger: I am the Lord your God (From Nelson's NKJV study Bible, 1997). The above law prevented the reapers from harvesting all crops from the field, but to leave some for the poor. This could be regarded as CSR in practice as the law was meant to the obeyed.

Several studies have been done on corporate social responsibility of firms and organizations. A number of these studies indicate that the understanding and practice of corporate social responsibility is related to the social and cultural life of the people (Amaeshi et al, 2006). Nevertheless, research on management and corporate social responsibility in Africa is very scarce and to a large extent dependent on a developing-developed world paradigm (Jackson, 2004). Studies on corporate social responsibility do exists in Nigeria, however it appears like most of such studies have concentrated mainly on multinational companies (Amaeshi et al, 2006) in the oil sector and very few on small and medium scale enterprises.

In the study of "ethics and social responsibility in the Nigerian Insurance industry: a multi- methods approach", Obalola (2007) assessed the perceived role of ethics and social responsibility for organisational effectiveness in a developing and African country. Using a mainly qualitative approach and aided by some quantitative analysis, the study explored the perceived importance of this construct (ethics and social responsibility) for organisational effectiveness among insurance managers in the Nigerian insurance industry. The study demonstrated that the perceived importance of ethics and social responsibility for organisational effectiveness is a function of industry and product nature, individual moral values, corporate ethical values and organisational commitment.

A similar study which was recently conducted by Olowokudejo et al (2011) indicated that insurance companies are involved in four forms of CSR which are business ethics, urban affairs, consumer affairs and environmental affairs. Moreover, the involvement in CSR correlated positively with organizational effectiveness In his study on "corporate social responsibility from a Nigerian perspective" Helg (2007), used primary data established that the concept corporate social responsibility is relatively new in Nigeria. He further noted this idea started off as a response to remedy the effects of their extractive activities by multinationals on the communities.

According to the study, corporate social responsibility in Nigerian can be seen from two directions. Firstly, the philanthropic nature of corporate social responsibility practices which is a recent development mainly driven by MNEs and large national companies. Secondly, there is the existence of informal CSR practices that are linked to cultural Nigerian traits, mostly found in the formal and informal sectors of Nigeria. Traditional values such as people/employees being treated as ends in them, as well as values like sharing and consensus are still strongly manifested in business life in Nigeria. However, Helg did not explore the formal and informal CSR practices within the SME sector Nigeria, a gap the present study seeks to fill.

\section{Methodology}

The choice of Cross River State is based on the fact the hotel industry in this part of the country has been witnessing tremendous growth since the return to democratic rule in 1999. The number of hotels in the state rose from less than 10 in 1999, to well over 123 in 2010 (Cross River State Tourism Bureau, 2011). This unprecedented growth is mostly catalysed by the State Government's drive in tourism development. The State currently rank's number one in the Country in terms of Tourism development. This has led to the recent appointment of a Cross Riverian as the Minister of Tourism, Culture and Orientation, by the President, Dr. Goodluck Ebele Jonathan, in 
the Federal Government's desire to replicate what has happened in Cross River State in other parts of the Country.

Some of the tourist attractions include the Obudu Mountain Resort, with the longest cable car in Africa, Tinapa Africa's Premier Business and Leisure Resort, The Marina Resort, The Agbokim Waterfalls, the Ikom Monoliths. Others include the Calabar Carnival, which is the longest street party in Africa covering a distance of 12 kilometres, held every 26th of December, the 32-days Christmas Festival, held every year from 30th of November - 1st of January of the following year, the Obudu Mountain International Race and the Leboku New Yam Festival. This places and programmes attract people from all over the world, thereby placing high demand on hotel accommodation. Also, it afforded the researchers the opportunity to be directly involved in the data collection as they are from this part of the Country.

Data for this study were obtained from the hotel industry in Cross River State of Nigeria, through the use of the questionnaire. The population of study was the 123 hotels properly registered with the Cross River State Tourism Bureau. The researchers would have loved to census the entire population but not for time and finance that was available for the study. According to Saunders, et al (2007), sampling provides a valid alternative to a census when it becomes impracticable to survey the entire population and time is a constraint. Hence, a sample was adopted for the study. A sample fraction of 3/10 (30 per cent) of the population was adopted for the study. Udofia (2011) asserts that a sample fraction of $1 / 10$ or more is deemed satisfactory as no serious research can progress with a sampling fraction of less than 10 per cent. Hence, a total of 37 hotels were sampled.

The simple random sampling technique was used to select the hotels to be sampled. This was done to eliminate bias in sampling by providing the opportunity for every hotel to have the chance of being sampled. In doing this the names of all the 123 hotels were properly written out on a sheet of paper and folded. The folded papers were placed in a container and shaken. The folded papers were then picked, one after the other, without replacement until the number of sample was reached. The selected hotels (Table 1) were then sampled through the managers and Managing Directors/Chief Executive Officers. This gave a total of 74 respondents.

Table 1. The sampled hotels

\begin{tabular}{clcl}
\hline Sample No. & Name of Hotel & Sample No. & Name of Hotel \\
\hline 1 & Bliss Mansion Hotel & 20 & Ekunikpa Hotel \\
2 & Amex Hotel & 21 & Rexona Hotel \\
3 & Doris 'O' Hotel & 22 & Unical Hotel \\
4 & Metropolitan Hotel & 23 & Eyo Achisco Hotel \\
5 & ATC Hotel & 24 & Forest Hotel \\
6 & Channel View Hotel & 25 & Marian Hotel \\
7 & Axari Hot & 26 & Formarc Hotel \\
8 & Cross Road Hotel & 27 & Mega Hilton Hotel \\
9 & Davvy Hotel & 28 & Boston Hotel \\
10 & Adrian's Hote & 29 & Bowman Hotel \\
11 & Beebobsco Hotel & 30 & Mirrage Hotel \\
12 & Royal Bit Hotel & 31 & Paradise City Hotel \\
13 & Design 2000 Hotel & 32 & Zoo Garden Hotel \\
14 & Blue Sea Hotel & 33 & Paladium Hotel \\
15 & Editas Hotel & 34 & Feeder Hotel \\
16 & Chalsma Hotel & 35 & Flaudros Hotel \\
17 & Edrosa Hotel & 36 & Pyramid Hotel \\
18 & Bowman Hotel Ltd & 37 & Cytaro Hotel \\
19 & Brow Land Hotel & & \\
\hline
\end{tabular}

Source: Cross River State Tourism Bureau, 2011.

The choice of the managers and CEO was based on the fact that if social responsibility is to be initiated, then these two figures should be aware and should be the right persons to have the information. This was also allowed to test the reliability of the data. The administration of copies of the questionnaire was done using field assistants. Out of 
the 74 copies that were administered, 66 of them were completed and returned. Eight (8) of the respondent from 4 hotels refused to respond. The active response rate was therefore 89.19 per cent. This was considered to be highly representative of the sample.

Meanwhile, questions for the research questionnaire were framed around attribute, opinion on CSR, organisation's behaviour towards CSR. These constituted the three major sections of the questionnaire. Section 1 was developed to obtain information on the respondents' attributes. According to Dillman (2000), attributes are best thought of the things a respondent possesses. They include characteristics such as gender, age, educational qualification, position in the organization, length of stay in the hotel, number of years of operations of the hotel, etc. section 2 was developed to obtain data on the respondents' opinion. Opinion variables record how respondents feel about something. Some of the items on this section include: 'there is awareness of CSR among the SME's', SME can serve as the engine room for CSR in Nigeria', etc. Section 3 was developed to obtained data on the behavior of the hotel industry toward CSR. Behaviour involves recording what respondents do. Items in this section were on levels of CSR of the hotels in different sectors including, education, infrastructure, environment, health and employment. The questions were all closed-ended.

A five-point Likert type scale (strongly agree - 5, agree - 4, no opinion - 3, disagree - 2 and strongly disagree - 1) was used to extract the data on respondents' opinion from the questionnaire. Similarly, another five-point Likert scale (very high level - 5, high level - 4, no level - 3, low level - 2, and very low level - 1) was used to extract the data on the respondents' behaviour toward CSR from the questionnaire. The mean was used in interpreting the data. The interpretation of the mean depends on the cut-off point computed by the researcher (Uzoagulu, 1998). The cut-off point was obtained by adding the weighting of the response categories and dividing by the number of categories. For the present study, the cut-off point was: $5+4+3+2+1=15 / 5=3.005$ The decision rule is that, any item or statement having a mean of 3.00 and above is interpreted as positive while anyone with mean below 3.00 is taken as negative.

\section{Results and Discussion}

Tables 2 to 5 present the attributes of the respondents in the study. Table 2 reveals that 39 males constituting 59.09 per cent and 27 females, constituting 40.91 per cent participated in the study. Hence, there were more males than females in the study population. Majority of the respondents were in the middle age of 31 and $45(48.49 \%)$.

Table 2. Distribution of gender and age of respondents

\begin{tabular}{ccccccc}
\hline \multirow{2}{*}{ Age (years) } & \multicolumn{3}{c}{ Gender } & \multicolumn{2}{c}{ Total } \\
\cline { 2 - 6 } & \multicolumn{3}{c}{ Male } & \multicolumn{2}{c}{ Female } & \\
\cline { 2 - 6 } & No. & $\%$ & No. & $\%$ & No. & $\%$ \\
\hline $18-30$ & 4 & 60.00 & 2 & 40.00 & 6 & 9.09 \\
$31-45$ & 18 & 56.25 & 14 & 43.75 & 32 & 48.49 \\
$46-60$ & 15 & 56.69 & 11 & 42.31 & 26 & 39.39 \\
60 and above & 2 & 100 & 0 & 0.00 & 2 & 3.03 \\
Total & 39 & 59.09 & 27 & 40.91 & 66 & 100 \\
\hline
\end{tabular}

Table 3. Position and educational qualification

\begin{tabular}{ccccccc}
\hline \multirow{2}{*}{$\begin{array}{c}\text { Educational } \\
\text { qualification }\end{array}$} & \multicolumn{3}{c}{ Position } & \multicolumn{2}{c}{ Total } \\
\cline { 2 - 5 } & \multicolumn{2}{c}{ CEO/MD } & \multicolumn{2}{c}{ Manager } & & \\
\cline { 2 - 5 } & No. & $\%$ & No. & $\%$ & No. & $\%$ \\
\hline FSLC & 0 & 0.00 & 0 & 0.00 & 0 & 0.00 \\
SSCE & 2 & 11.76 & 15 & 88.24 & 17 & 25.76 \\
NCE/OND & 7 & 33.33 & 14 & 66.67 & 21 & 31.82 \\
HND/BSC & 19 & 82.61 & 4 & 17.39 & 23 & 34.85 \\
Postgraduate & 5 & 100 & 0 & 0.00 & 5 & 7.57 \\
Total & 33 & 50.00 & 33 & 50.00 & 66 & 100.00 \\
\hline
\end{tabular}


Table 4. Length of stay in the Hotel

\begin{tabular}{ccccccc}
\hline $\begin{array}{c}\text { Length of stay in the } \\
\text { hotel (Years) }\end{array}$ & \multicolumn{3}{c}{ Position } & \multicolumn{3}{c}{ Total } \\
\cline { 2 - 5 } & \multicolumn{2}{c}{ CEO/MD } & \multicolumn{2}{c}{ Manager } & & \\
\cline { 2 - 5 } & No. & $\%$ & No. & $\%$ & No. & $\%$ \\
\hline$<1$ & 0 & 0.00 & 0 & 0.00 & 0 & 0.00 \\
$1-5$ & 17 & 44.74 & 21 & 55.26 & 38 & 57.58 \\
$6-10$ & 12 & 50.00 & 12 & 50.00 & 24 & 36.36 \\
$11-15$ & 4 & 100 & 0 & 0.00 & 4 & 6.06 \\
$>15$ & 0 & 0.00 & 0 & 0.00 & 0 & 0.00 \\
Total & 33 & 50.00 & 33 & 50.00 & 66 & 100.00 \\
\hline
\end{tabular}

Table 5. Information on the hotels

\begin{tabular}{ccc}
\hline Years of operation (Years) & No. & $\%$ \\
\hline$<1$ & 0 & 0.00 \\
$1-5$ & 17 & 51.52 \\
$6-10$ & 11 & 33.33 \\
$11-15$ & 3 & 9.09 \\
$>15$ & 2 & 6.06 \\
Total & 33 & 100.00 \\
\hline
\end{tabular}

From Table 3, it is clear that 33 persons each on the CEO/MD and Manager categories actually participated in the research. Majority of the respondents possessed the Higher National Diploma and the Bachelors degree. This class of respondents accounted for 34.85 per cent of the sample. Table 4 shows that majority of the respondents have been working in these hotel in last five years $(57.58 \%$ ). All other respondents have worked for more than five years in these organizations. None of the respondents appears to be new to the hotels' activities, hence they are here adjudge to be the proper sample for the study. From Table 5, majority of the hotels are not older than 5 years $(51.52 \%)$. Only two of the hotels have been in existence for a period greater than 15 years. This reveals that most of the hotels sprang up in the current democratic dispensation which is only twelve years old. Table 6 presents the opinion of respondents with respect to CSR.

Table 6. Opinions on corporate social responsibility

\begin{tabular}{|c|c|c|c|c|c|c|c|}
\hline \multirow[t]{2}{*}{ Statements on CSR } & \multicolumn{5}{|c|}{ Scores } & \multirow[t]{2}{*}{ Mean } & \multirow[t]{2}{*}{ Decision } \\
\hline & 5 & 4 & 3 & 2 & 1 & & \\
\hline 1.There is awareness of CSR among the SMEs & 2 & 7 & 8 & 37 & 12 & 2.24 & Reject \\
\hline $\begin{array}{l}\text { 2. SMEs can serve as the engine room for CSR in } \\
\text { Nigeria }\end{array}$ & 34 & 24 & 4 & 4 & 0 & 4.33 & Accept \\
\hline 3.CSR can help improve the image of business & 33 & 27 & 3 & 3 & 0 & 4.36 & Accept \\
\hline 4. My hotel has CSR in its formal form & 0 & 4 & 11 & 42 & 7 & 2.12 & Reject \\
\hline 5. My hotel has CSR in its informal form & 14 & 35 & 3 & 13 & 1 & 3.73 & Accept \\
\hline 6. CSR should be practice by SMEs & 18 & 40 & 3 & 4 & 1 & 4.01 & Accept \\
\hline $\begin{array}{l}\text { 7. The tourism industry led by hotel outfits should } \\
\text { pioneer CSR in Cross River State in particularly and } \\
\text { Nigeria in general }\end{array}$ & 21 & 32 & 5 & 4 & 4 & 3.94 & Accept \\
\hline
\end{tabular}

From Table 6, the statement 'there is awareness of CSR among the SMEs' has a mean value of 2.24. This was 
interpreted as negative since it is below the cut-off point of 3.00. Hence, the result reveals that awareness on CSR in the hotel industry is low. Helg (2007) also made similar finding. However, it was the opinion of the respondents that SMEs can serve as the engine room for CSR in Nigeria. This conclusion was reached based on the fact that the mean in this case is 4.33 , which is higher than the cut-off point of 3.00. Also, the respondents agree that CSR can help improve the image of their business. This is supported with a mean of 4.36. The statement 'my hotel has CSR in its formal form' has a mean value of 2.12. This value is below the 3.00 cut-off mark, hence it was considered to be negative. In view of this, the statement was rejected. It therefore means that there is no formal CSR in hotel industry. However, CSR exist in its informal form. The opinion of the respondents has a mean value of 3.73 which is above the 3.00 cut-off mark. On whether CSR should be practiced by SMEs, the consensus of the respondents was in the positive with a mean value of 4.01. the respondents also believed that the tourism industry, led by hotel outfits should pioneer CSR in Cross River State, in particular and Nigeria in general (Mean = 3.94).

Table 7 presents information on the behaviour of respondents towards CSR.

Table 7. Level of involvement in CSR by hotels in different sectors

\begin{tabular}{llllllll}
\hline Sector & \multicolumn{5}{c}{ Scores } & Mean & Decision \\
\cline { 2 - 6 } & 5 & 4 & 3 & 2 & 1 & & \\
\hline 1. Education & 9 & 17 & 8 & 25 & 7 & 2.94 & Reject \\
2. Infrastructure & 6 & 15 & 6 & 30 & 9 & 2.68 & Reject \\
3. Environment & 10 & 28 & 7 & 18 & 3 & 3.36 & Accept \\
4. Health & 7 & 19 & 7 & 26 & 7 & 2.89 & Reject \\
5. Employment & 22 & 32 & 3 & 5 & 4 & 3.95 & Accept \\
\hline
\end{tabular}

It reveals the extent to which hotel industry is involved in CSR in different sectors of the economy. With respect to the educational sector, the mean value of 2.94 was recorded. This is in the negative. This implies that the level of involvement of hotels in CSR in the area of education is low. Similarly, the hotel industry also recorded a low level of involvement in infrastructural development. This is reflected in the mean (2.68) that has been computed for that sector. On the other hand, environment sector witnessed a high level of involvement in CSR by the industry under study. This is evidenced in the mean score that is recorded by this sector. Hence, it can be deduced that hotels in the study area involves in environmental management programmes. Although the hotel industry involves in health programmes, the study reveals that the level of involvement is low (mean $=2.89)$. However, the study reveals a significant contribution of the hotel industry to CSR in the area of employment (mean 3.95).

\section{Conclusion}

In view of the findings of the present study, it is concluded that there is low level of awareness of CSR among the SMEs. SMEs can serve as the engine room for CSR in Nigeria. CSR does not exist in its formal form in SMEs. However, CSR exists in its informal form. It was the opinion of the respondents that CSR should be practiced by SMEs, and the tourism industry, led by hotel outfits could pioneer CSR in Cross River State, in particular and Nigeria in general. This study also looked at the behaviour of the hotel industry towards CRS. In this regard, it was found out that the level of involvement of hotels in CSR in the area of education is low. Similarly, there is also low level of involvement in infrastructural development. On the other hand, the environment sector witnessed a high level of involvement in CSR by the industry under study. Hence, hotels in the study area involve in environmental management programmes. Moreover, although the hotel industry involves in health programmes, the study reveals that the level of involvement is low. It is also concluded that there is significant contribution of the hotel industry to CSR in the area of employment. It is recommended that CSR should be embraced by the SMEs in order to fast track the country's overall development. However, this study did not examine the factors that are responsible for the negative aspect on the SMEs vis-à-vis the hotel industry. This could become the focus of further research.

\section{References}

Adebayo, A. (1998). Public relations in banking. The strategic imperative in the Nigerian banking sector.

Amaeshi, K. M., Adi, B. C., Ogbechie, C., \& Amao, O. O. (2006). Corporate social responsibility (CSR) in Nigeria: western mimicry of indigenous practices? ICCSR Research Paper Series. The University of Nottingham Business School. 
Ariyo, D. (2005). Small firms are the backbone of the Nigerian economy. Retrieved August 14, 2009 from $\mathrm{http} / / /$ www.africaneconomicanalysis.org

Azende, T. (n.d). Corporate social responsibility in Nigerian banking system: the development of small and medium scale enterprises. Retrieved from http://www.wbiconpro.com/615-Azende

Barrett, R. (1998). Liberating the Corporate Soul: Building Visionary Organizations. Butterworth Heinemann, Oxford: Bereau of Public Enterprises.

Bowen, H. R. (1953). Social responsibilities of the businessman. New York: Harper and Row.

Branco, M. C., \& Rodriques, L. L. (2007). Positioning stakeholder theory within the debate of corporate social responsility. Electronic Journal of Business Ethics and Organization Studies, 12(1).

Cross River State Tourism Bereau. (2011). Year Book.

Crowther, D. (2004). Corporate social reporting: guinuine action or window dressing? In Crowther, D., \& Rayman-Bacchus, L. (Eds.), Perspectives on Corporate Social Responsibility. Aldershot, Hants: Ashgate

Crowther, D., \& Jatana, R. (2005). Is CSR Profitable? In Crowther, D., \& Tatana, R. (Eds.), Representations of Social Responsibility (Vol. 1). Hyderabad: ICFAI University Press.

Crowther, D., \& Rayman-Bacchus, L. (2004). Perspectives on corporate social responsibility (p. 3). Ashgate Publishing Limited.

Dillman, D. A. (2000). Mail and internet surveys: the tailored design method (2nd ed.). New York: Wiley.

Harrison, J. G., \& Freeman, R. E. (1999). Stakeholders, social responsibility, and performance: empirical evidence and theoretical perspectives. Academy of Management Journal, 42(5), 479-485. http://dx.doi.org/10.2307/256971

Helg, A. (2007). Corporate social responsibility from a Nigerian perspective. A Masters Thesis, Management and Organisation, Handelshogskolan.

Hodgson, S. (2005). Corporate social responsibility: it's compelling good business to give something back to Nigerian. The Guardian, 21(9690), 15.

Jackson, T. (2004). Management and change in Africa (pp. 2, 6). Routledge.

Kpelai, T. (2009). Entrepreneurship development in Nigeria. Makurdi: Aboki Publishers.

National Planning Commission, Abuja. (2004).

Nelson's New King James Version Study Bible. (1997). Thomas Nelson, Inc.

Obalola, M. A. (2010). Ethics and social responsibility in the Nigerian insurance industry: a multi-methods approach. A doctoral degree thesis, submitted to De Montfort University, Leicester.

Olowokudejo, F., Aduloju, S. A., \& Oke, S. A. (2011). Corporate social responsibility and organizational effectiveness of insurance companies in Nigeria. Journal of Risk Finance, 12(3), 156-167. http://dx.doi.org/10.1108/15265941111136914

Operational Guidelines of Small and Medium Enterprises Equity Investment scheme SMEEIS. (2005).

Saunders, M., Lewis, P., \& Thornhill, A. (2007). Research methods fro business students (4th ed.). England: Pearson Education Limited.

Udofia, E. P. (2011). Applied Statistics with multivariate methods. Enugu: Immaculate Publishing Limited.

Umoh, P. N. (1983). Corporate goals and social responsibility in the Nigerian banking industry. In Osaze, B. E. et al (Eds.), Business Ethics and social responsibility in Nigeria (pp. 148-158). Department of Business Administration, Ahmadu Bello University, Zaria.

Wikipedia. Retrieved from http://wikipedia.org

Windell, K. (2006). Corporate social responsibility under construction ideas, translational and institutional change. Doctoral Thesis No. 123, Uppsala Universitet, pp. 5 \& 8.

\section{Copyrights}

Copyright for this article is retained by the author(s), with first publication rights granted to the journal.

This is an open-access article distributed under the terms and conditions of the Creative Commons Attribution license (http://creativecommons.org/licenses/by/3.0/). 